[Original]

\title{
Unique Chimeric Composition of the Trehalase Gene from Brine Shrimp, Artemia franciscana
}

\author{
Shin TANAKA ${ }^{1}$, Fumiko NAMBU ${ }^{1}$ and Ziro NAMBU ${ }^{2}$ \\ 'Division of Human, Information and Life Sciences, School of Health Sciences, University of Occupa- \\ tional and Environmental Health, Japan. Yahatanishi-ku, Kitakyushu 807-8555 Japan \\ ${ }^{2}$ Kyushu International College of Nursing, The Japan Red Cross. Munakata 811-4157 Japan
}

Abstract: To investigate the exon/intron structure of the Artemia trehalase gene, four overlapping clones were isolated from a genome library derived from an inbred strain of crustacean Artemia franciscana, and a $49 \mathrm{~kb}$ genetic area was re-constructed. The re-constructed area contained eight exons corresponding to the trehalase cDNA sequence that we had previously reported [1]. Comparative analysis of the Artemia trehalase gene with other animal trehalase genes revealed the existence of conserved exon/intron boundaries among different phyla. Comparison of the 5' UTR region of trehalase mRNA obtained by the 5 ' RACE method with the trehalase genes indicated the existence of a novel exon/intron boundary in the region designated "Exon I". Surprisingly, a part of a mitochondrial ribosomal protein gene (MRP-S33) was found to be inserted in the 5' UTR region of the trehalase gene. This sequence had the same polyadenylation signal that the Artemia MRP-S33 cDNAs did. Using the 3'RACE method, it was demonstrated that the poly (A) additional signal is still functional and that the chimeric mRNAs composed of the 5' UTR of the trehalase mRNA and of the 3' end derived from the MRP-S33 gene are transcribed.

Key words: anhydrobiosis, Artemia, brine shrimp, alternative splicing, alternative polyadenylation.

(Received 16 November 2009, accepted 1 February 2010) 


\section{Introduction}

Many organisms accumulate $\alpha, \alpha$-trehalose as a protectant against desiccation and freezing [2,3]. Dormant Artemia cysts also store trehalose and have been shown to be highly resistant to desiccation [4]. After breaking diapause, Artemia resume their development and the stock of trehalose is hydrolyzed by trehalase (EC 3.2.1.28) [5].

To date, literature on the genes of animal trehalase has been accumulated. The trehalases reported from mammals were allocated in the small intestine and kidney [6-9]. The trehalases reported from the small intestine are thought to work as a digestive enzyme to catalyze the hydrolysis of trehalose contained in food, such as mushrooms [6], whereas the function of trehalases in the kidney is still unclear. On the other hand, trehalases reported from insects are essential enzymes to utilize trehalose, the main blood sugar of insects. Two types of insect trehalase are known: membrane-bound trehalase located on the cell membrane, and soluble trehalase contained in the cell matrix [10-14]. In the silkworm, soluble and membrane-bound trehalases are each coded by independent genes, trehalase-1 [15] and trehalase-2 [16]. The two genes are quite different from each other, especially in their nucleotide sequence.

We reported that Artemia trehalase protein predicted from cDNA had a putative transmembrane region [1], whereas purified Artemia trehalase was a soluble type [5]. We supposed that the soluble trehalase was generated by the cleavage of the transmembrane region because the molecular mass of the soluble trehalase was almost the same as that of a protein encoded by cDNAs without a "transmembrane" region [1]. Although the assumption could be reinforced by analyzing a copy number of the trehalase gene, previous southern blot analyses using cDNA probe were not clear because the boundaries of exons were not known [17]. These reports also suggested alternative splicing or switching of transcriptional start site occurred $[1,17]$. However, details of mRNA variants or exon/intron structure of the Artemia trehalase gene have not been reported, either. We screened the genomic library of Artemia to obtain clones of the trehalase gene, and the Artemia trehalase gene was re-constructed using these clones. In the present paper, we report the unique structure of the Artemia trehalase gene. We also analysed a copy number of the trehalase gene using appropriate probes based on the exon/intron structure of the Artemia trehalase gene.

\section{Materials and Methods}

\section{Animals}

Cysts of Artemia franciscana from the Great Salt Lake (Utah, USA) were purchased from Japan Pet Drugs Co. Ltd. (Tokyo, Japan and Los Angeles, CA, USA). The cysts were hydrated and allowed to develop under appropriate conditions $\left(2 \%\right.$ sea salt water, $28^{\circ} \mathrm{C}$ under 
constant light). Hatched nauplii were fed with Baby shrimp food (NT Laboratories Ltd., East Peckham, UK). Mature adults were mated in isolated beakers and their descendants were used to establish inbred strains as described by Nambu et al . [18]. Individuals at F22F24 belonging to a single inbred strain were collected, starved for two days, and used to construct a genomic library.

\section{Construction and screening of genomic library}

After being washed with sea salt water, adult Artemia were homogenized in a DNA extraction buffer (10 mM Tris, $10 \mathrm{mM}$ EDTA and $100 \mathrm{mM} \mathrm{NaCl}, \mathrm{pH} \mathrm{0.8)}$ and incubated overnight with $0.5 \%$ SDS and $0.2 \mathrm{mg} / \mathrm{ml}$ proteinase $\mathrm{K}$ at $37^{\circ} \mathrm{C}$. Genomic DNA was extracted three times with an equal volume of phenol and collected by ethanol precipitation. The DNA was dissolved in a solution containing $10 \mathrm{mM}$ Tris ( $\mathrm{pH} 8.0), 0.1 \mathrm{mM}$ EDTA and $2 \mu \mathrm{g} / \mathrm{ml}$ RNase A (WAKO Pure Chemical Industries Ltd, Osaka, Japan). After RNase treatment (at $37^{\circ} \mathrm{C}$ for $1 \mathrm{hr}$ ), $0.5 \% \mathrm{SDS}$ and $0.1 \mathrm{mg} / \mathrm{ml}$ proteinase $\mathrm{K}$ (SIGMA-Aldrich Corporation, St. Louis, USA) were added to the solution and further incubated for $3 \mathrm{hr}$. The DNA was deproteinated by phenol extraction followed by chloroform extraction, and was precipitated with ethanol.

Finally, the DNA was redissolved in TE buffer ( $1 \mathrm{mM}$ EDTA and $10 \mathrm{mM}$ Tris-HCl, $\mathrm{pH}$ 8.0). The genomic DNA was partially digested with Sau3AI and was ligated into the Bam $\mathrm{HI}$ site of an EMBL3 phage and packaged into a lambda phage particle using gigapack ${ }^{(\mathrm{R}}$ III Gold (Stratagene Cloning System, La Jolla, CA, USA).

A trehalase cDNA clone, called TreE2 [1], was labeled using a DIG DNA Labeling Kit (Roche Molecular Biochemical, Basel, Switzerland) and used as a probe. Approximately $5.0 \times 10^{5}$ plaque-forming units (pfu) of recombinant phages were plated with the Escherichia coli XL1-Blue MRA (P2) strain. The phage plaques were transferred to a nylon membrane, as described by Sambrook et al. [19]. Phage clones containing the Artemia trehalase gene were detected by a DIG-labeled probe according to a method described by Engler-Blum et al . [20]. Although four clones ( $\lambda$ gTre9, 11, 13 and 23) were obtained by the screening, these clones did not have regions corresponding to the 5' and 3' end sequences of the TreE2. Additional screenings were performed to obtain the missing genomic regions using DIG-labeled PCR probes. Probe I was synthesized using the primers TreEX1sen and TreEX1ant (see Table 1) to detect the upstream region of the Artemia trehalase. Probe VII was synthesized using the primers TreEX7sen and TreEX7ant (Table 1) to obtain the genetic region corresponding to the 3 ' end of the trehalase cDNA. As a result of additional screenings, $\lambda \mathrm{g}$ Tre $44, \lambda \mathrm{gTre} 68-1$ and $\lambda \mathrm{gTre} 70$ were isolated. Four overlapping clones $(\lambda \mathrm{g}$ Tre9, 11,44 and 68 1) were selected and sequenced to re-construct the Artemia trehalase gene.

\section{Sequencing of genomic clones}

Specimens of lambda DNA extracted from each clone were digested by SalI. SalI frag- 
Table 1. Primers used in this paper

\begin{tabular}{|c|c|c|c|}
\hline primer & sequence( $\left(5^{\prime}\right.$ to $\left.3^{\prime}\right)$ & position & direction \\
\hline TreEX1sen & GTGAGAACACTGTATACAATAC & 7908-7929( a) & sense \\
\hline TreEX1sen.new & GTGAGAACACTGTATACAATA & $7908-7928(\mathrm{a}, \mathrm{b})$ & sense \\
\hline TreEX1ant & CTAGCACAAACAGGCGGTAG & $8256-8275($ a) & antisense \\
\hline TreEX4SEN & GCAAAACATTCACCTGTTGG & $25584-25603($ a) & sense \\
\hline TreEX4ANT & TCTACAGGTAGTATGTCACG & $25864-25883($ a) & antisense \\
\hline TreEX6SEN & TATGACGTAACGGTCGTTGG & $32675-32694($ a) & sense \\
\hline TreEX6ANT & CCAATCCAAGCACCGAGG & $32869-32876($ a) & antisense \\
\hline TreEX7sen & TCTTGCAAGTACTCGATTCTAT & $42543-42564($ a) & sense \\
\hline TreEX7ant & TTTACTAAGAAAATATCACACTCG & $47196-47219$ ( a) & antisense \\
\hline TreRACE.A2 & TATGCAGGAATGTTCCATGG & $17569-17588($ a) & antisense \\
\hline TreRACE.A1 & GATTTTGATCGGTTGAGTTC & $17689-17708($ a) & antisense \\
\hline TreRACE.S1 & GGGTCAGAATTTGAAGAATG & $17759-17778(a, b)$ & sense \\
\hline TreRACE.S2 & GATTGGCATTCTAACCCAAG & $17789-17808(a, b)$ & sense \\
\hline TreRT-1 & ATATATCCTTCCACCATTGG & $22396-22415($ a)* & antisense \\
\hline TreRACE.A1-2 & CСTCTTTGAAATCCTGATGTTC & 8014- 8035(a,b) & antisense \\
\hline TreRACE.S1-2 & GGAGAAGGCAAACGTGCAAG & $8083-8102($ a) & sense \\
\hline TreRACE.S2-2 & ATCTGATTCTCAGTGAAAGAGC & $8227-8248($ a) & sense \\
\hline TreRT-2 & 3CTAGCACAAACAGGCGGTAG & 8256- $8275(\mathrm{a}, \mathrm{b})^{*}$ & antisense \\
\hline TreUnkSEN & TCTTAAGCCTTCCAGCGAGT & $(\mathrm{b})$ & sense \\
\hline TreUnkANT & AACACCTTGTAGACCAATCTTG & $(\mathrm{b})$ & antisense \\
\hline MRP-S33sen & TTTCTAAGATCAGCATTATTTGG & $(\mathrm{c})$ & sense \\
\hline MRP-S33ant & AACCATAAAGTCTTAAATGCTTC & ( c) & antisense \\
\hline Oligo dT 3' -sites Adaptor & CTGATCTAGAGGTACCGGATCC(T)n & ( d) & \\
\hline 3' -sites Adaptor & CTGATCTAGAGGTACCGGATCC & $(\mathrm{d})$ & \\
\hline
\end{tabular}

(a): Nucleotide number is based on reconstructed trehalase gene illustrated in Fig. 1,(b): position of the primer is illustrated in Fig. 3, (c): position of the primer is illustrated in Fig. 4A, (d): involved in 3' RACE core kit, $*$ : phosphorylated at 5' end

ments of the trehalase gene were inserted into a pBluescript SK(-). Subclones were constructed using restriction endonucleases, and overlapping clones were generated from each subclone using a Kilo-Sequence Deletion Kit (Takara bio, Otsu, Japan). DNA sequencing was carried out using a BigDye $\left.{ }^{(}\right)$Terminator v3.1 Cycle Sequencing Kit and ABI PRISM ${ }^{(B)}$ 377 (Applied Biosystems).

\section{RNA extraction}

Fully washed and hydrated cysts or 12 h-cultured embryos of wild type A. franciscana were homogenized in ten volumes of ISOGEN (NIPPON GENE, Tokyo, Japan). Total RNA was isolated according to the manufacturer's protocol.

Rapid amplification of the 5' and 3' cDNA ends (RACE)

We analyzed the 5' end of Artemia trehalase mRNA according to the cRACE method, a 
modified 5' RACE method described by Maruyama et al [21]; it was performed according to the manufacturer's protocol of the 5'Full RACE Core Set (Takara bio, Otsu, Japan). The samples of total RNA were reverse-transcribed into single stranded cDNAs using a TreE2 specific primer (TreRT-1, Table 1) and AMV Reverse Transcriptase XL (Takara bio, Otsu, Japan). The cDNA chains were self-ligated by T4 RNA ligase and were made into circular forms. Nested PCR reactions were performed using trehalase-specific primers as follows: TreRACEA1 and TreRACES1 were used in the first amplification, and TreRACEA2 and TreRACES2 were used in the following amplifications (Table 1).

The results of the 5' RACE strongly suggested that alternative splicing occurred in the trehalase 5' UTR region called "Exon I". To detect the 5' end of the novel sequence found upstream of the new splicing site, an additional 5' RACE was performed using the following primers (Table 1 and Fig. 3): TreRT-2, a primer for reverse transcription; TreS1-2 and TreA1 -2, primers for the first amplification; TreS2-2 and TreA2-2, primers for the second amplification.

To detect the products of the alternative splicing, 3' RACE was performed according to the manufacturer's protocol of the 3' -RACE Core Kit (Takara bio, Otsu, Japan). Primers corresponding to different $5^{\prime}$ ends of trehalase mRNA (TreEX1sen.new or TreUnkSEN, Table 1) were used with a poly $(\mathrm{dT})$ primer in the 3' RACE reaction. The PCR products were subcloned into the EcoRV site of the pBluescript SK (-) and sequenced as described above.

Isolation and phylogenetic analyses of a novel cDNA corresponding to a sequence inserted into trehalase gene structure

To obtain variants of trehalase cDNA, the region corresponding to Exon I was DIG-labeled by PCR reaction using TreEX1sen and TreEX1ant primers (Table 1). The $\lambda \mathrm{gt10}$ library of $12 \mathrm{hr}$ cultured embryos [1] was plated with the Escherichia coli NM514 strain. Plaque lifting to nylon membranes and detection of positive clones were performed as described by Engler-Blum et al [20], followed by washing at $65^{\circ} \mathrm{C}$. Not I digested samples of lambda DNA extracted from each clone were inserted into the pBluescript SK (-) and sequenced as described in "Sequencing of genomic clones". An amino acid sequence coded by one of the clones was unexpectedly shown to have a high similarity to a known mitochondrial ribosomal protein gene, as described in the "Results" section. GENETYX ver.13 (GENETYX, Tokyo, Japan) was used to draw a phylogenetic tree of homologous proteins.

\section{Northern blot analysis}

In order to detect the mRNA of the mitochondrial ribosomal protein gene, a DIG-labeled PCR probe was synthesized from the subcloned cDNA (Fig.4A), using sequence-specific primers (MRP-S33sen and MRP-S33ant in Fig.4A). Samples of total RNA were extracted from re-hydrated dried cysts and $12 \mathrm{hr}$ developed embryos. Each specimen $(20 \mu \mathrm{g})$ was electrophoresed in a 1.0\% agarose gel containing formaldehyde [19], and blotted onto Hy- 
bondN+ membrane (Amersham). Hybridization was performed at $68^{\circ} \mathrm{C}$, as described by Engler-Blum et al [20], followed by washing at $65^{\circ} \mathrm{C}$.

\section{Southern blot hybridization}

Three DIG-labeled PCR probes corresponding to Exon I, Exon IV and Exon VI of the Artemia trehalase were synthesized and used in the following analysis. The primers used in the probe synthesis are described in Table 1: TreEX1sen and TreEX1ant for probe I; TreEX4 SEN and TreEX4ANT for probe IV; TreEX6SEN and TreEX6ANT for probe VI.

Genomic DNA was prepared from $20 \mathrm{hr}$-cultured and fully washed wild type larvae (nauplii) as described in "Construction and screening of genomic library", and digested by four kinds of restriction enzyme (Eco RI, Hind III, Bam HI and Pst I). The digested specimens were separated by electrophoresis through a $0.6 \%$ agarose gel and transferred to Nylon membranes. Fragments of the trehalase gene were detected as described in "Northern blot analysis".

\section{Results}

Re-construction of the Artemia trehalase gene

Four genomic clones ( $\lambda$ gTre9, 11, 13 and 23) were isolated by the first screening using the whole trehalase cDNA probe. Though the clones contained five exons corresponding to known trehalase cDNA, 5' and 3' ends of the cDNA were not found in these clones. In additional screenings, $\lambda$ gTre44, $68-1$ and 70 were obtained. Four clones $(\lambda \mathrm{gTre} 9,11,44$ and 68-1) were selected to re-construct the Artemia trehalase gene (Fig. 1). The identities be-

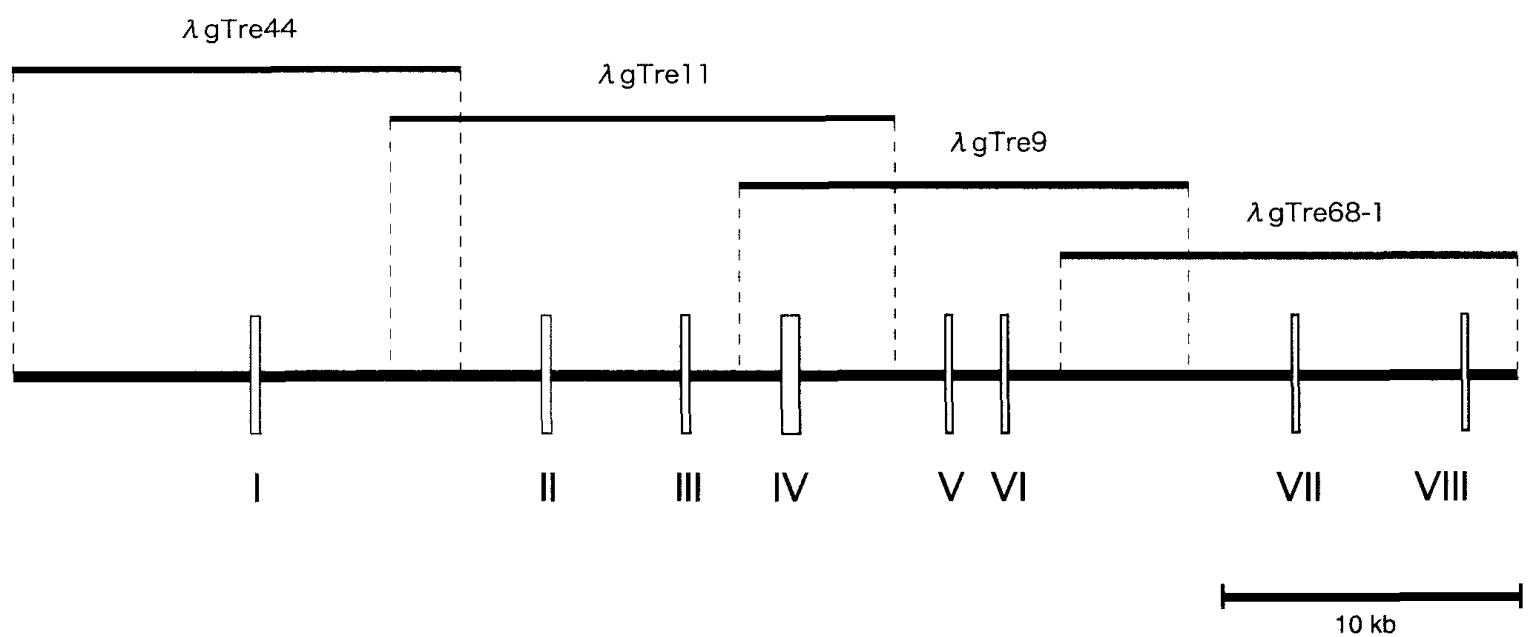

Fig. 1. Trehalase gene structure of Artemia franciscana. Eight exons corresponding to trehalase cDNAs [1] are designated as Exon I-Exon VIII. 
tween the genomic clones were higher than $99 \%$ in their overlapping areas. The reconstructed genetic area spanned about $49 \mathrm{~kb}$ (accession number of Genbank/EMBL/DDBJ: AB 458252) and contained eight exons (Exon I-Exon VIII, see Fig. 1) corresponding to known trehalase cDNA, TreE2 and E3 [1]. The protein encoded by the trehalase gene was aligned with animal trehalases, and the positions of the exon/intron boundary were compared. Boundaries corresponding to the position S38 and K526/Y527 were widely conserved among the animal trehalases (Fig. 2).

A new exon/intron boundary found in "Exon I" and alternative splicing of the Artemia trehalase gene

The 5' ends of some transcripts obtained by 5' RACE were different from those of reported cDNA clones, suggesting the existence of an unknown transcriptional start site. We verified a new exon/intron boundary in the exon designated "Exon I" (Fig. 3). It is probable that splicing at this site might occur according to the "GT-AG" rule, as with other splicing sites found in the Artemia trehalase gene. In order to detect the sequence of the 5' end of the new transcript, an additional 5' RACE was performed. The maximum length of the new 5' end sequence was 114 bp from the new exon/intron boundary found in Exon I (" 5 ' RACETreA6", Fig. 3).

A short sequence inserted in the trehalase gene: the sequence derived from a mitochondrial ribosomal protein gene, ArMRP-S33

The results of the 5'RACE suggested that Artemia trehalase mRNA had at least two variants in its 5 ' end. To confirm the existence of these variants, we re-screened the cDNA library of $12 \mathrm{hr}$-developed nauplii [1] using the Exon I as a probe. Only two clones were isolated by the screening of 200,000 clones. One of them was a fragmented 5' end of trehalase mRNA containing the new 5' end found by 5' RACE (data not shown). The other was $430 \mathrm{bp}$ long and had an open reading frame $(375 \mathrm{bp})$. The cDNA was composed of a novel sequence of 296 nucleotides and 134 nucleotides that were identical to the sequence downstream of the new exon/intron boundary found in the Exon I described above (Fig. 4A).

The protein predicted by the 375 bp ORF comprised 116 amino acids (Fig. 4A). The protein showed a high degree of similarity to a small subunit of mitochondrial ribosomal protein, MRP-S33 [22] reported from higher eukaryotes: 65\% to fruit fly (AE014297), 62\% to silkworm (DQ311287), malaria mosquito (AAAB01008859) and rat (DQ480753), 60\% to clawed frog (BC084770) and yellow fever mosquito (CH477286), 59\% to mouse (BC 092135 ) and human (BC105793), 58\% to bovine (BC109522), 56\% to rainbow trout (AB 161470), 53\% to zebrafish (BC095219), and 48\% to Caenorhabditis elegans (Z54271) and C. briggsae (CAAC02000533). In phylogenetic analyses, Artemia MRP-S33 (ArMRP-S 33, Genbank/EMBL/DDBJ accession no. AB456740) was allocated into the group of arthropod MRP-S33 proteins (Fig. 4B). The location of ArMRP-S33, on the branch next to that 
Fig. 2. Intron-inserted sites of animal trehalases. Trehalase proteins of Artemia (Af), silkworm (Bm-1

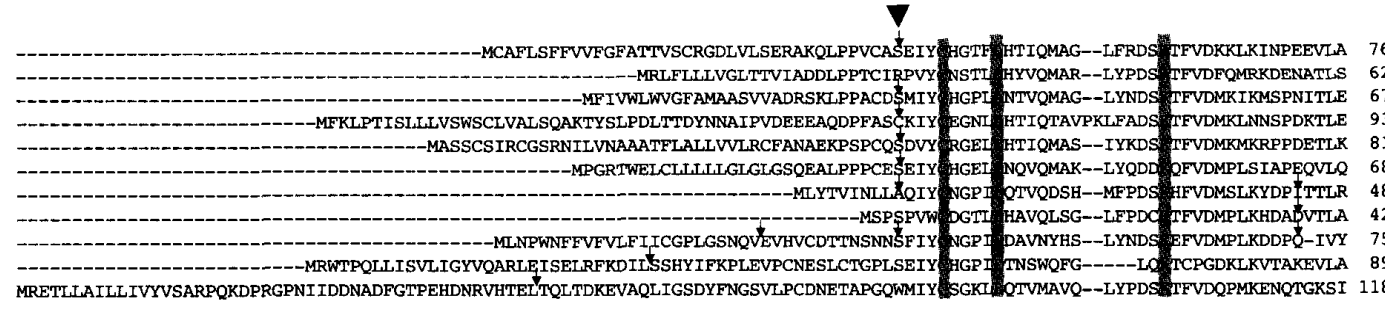

\begin{tabular}{|c|c|c|}
\hline 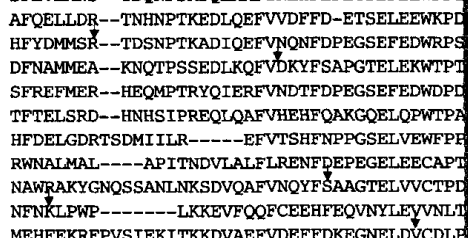 & 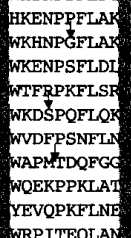 & 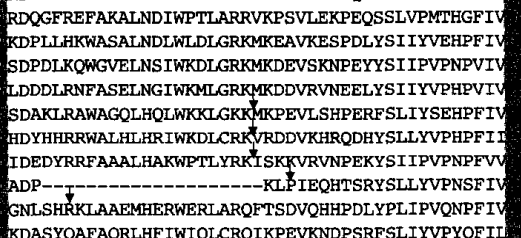 \\
\hline
\end{tabular}

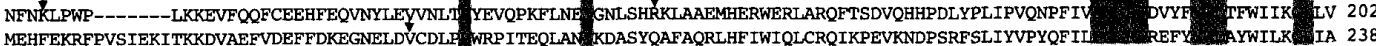

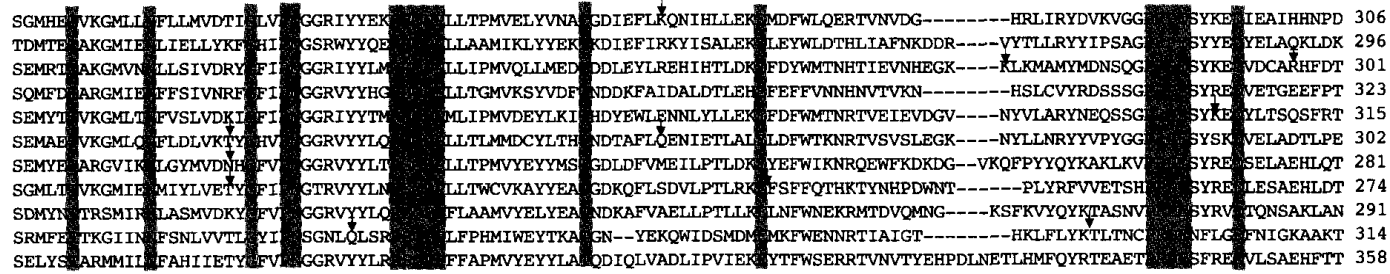

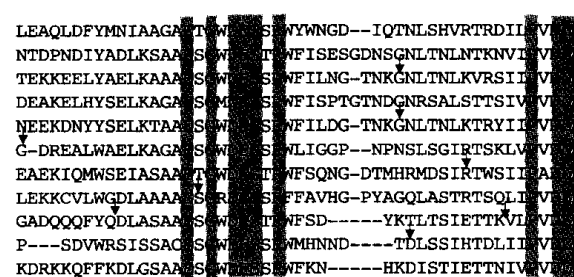
FIAWDFDIMSRFEKOLGRDNASWVYSDLYSEWKTSINALLWDDEAGS VIVIVDSAHRRWNTNFYVSNLT 424 IFAGALOITANFQAILKNPRRAAHWGYMAEOWRSSIEQALWDEEDGV : MDILNNKPRRYFYTSNLA 416 ILCWNAQIMMEYHTRLONEEKASYYRRIHDDFMEAIEELLWHEDVGY $\%$ YSIESSRRRDYFYPSNLS 420 YLYWNAKLIAEFHSKAGNTXKVTEYETKAEKLILGIOEVLWNEEAGY H YOMTNOKPRDYYTPTNLS 443 IIYRNAVLLAQYNQRMGNESKVAYYQKRAAENKRAIQAVLWHDEVGA $\%$ YDILNDIKRDYFYPTNIL 434 QFLCQAEETMSNFYSRLGNDSQATKYRTIRSQRTAAATNTVLWDEOTGA Y YDLEKKKKNREFYPSNLT 420 FMCANARILASL YEIAGDFKKVKVFEORYTWAKREMRELHWNETDGI Y Y YDIELKTHSSOYYVSNAV 400 IICGNMKTLSEMYTVCGDLESAKYFDNEYRTLRDTIRQULWNEEHNC F DVEEENHATSFHDTNFF 393 EILCWMMDIMEYLYEOIGDTKNSOIFRNKRADFRDTVONYFYNRTDGTT T MNLRTOSHNPRFYTSTAV 406

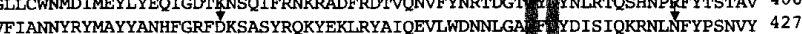
KDRKKOFFKDIGSAA

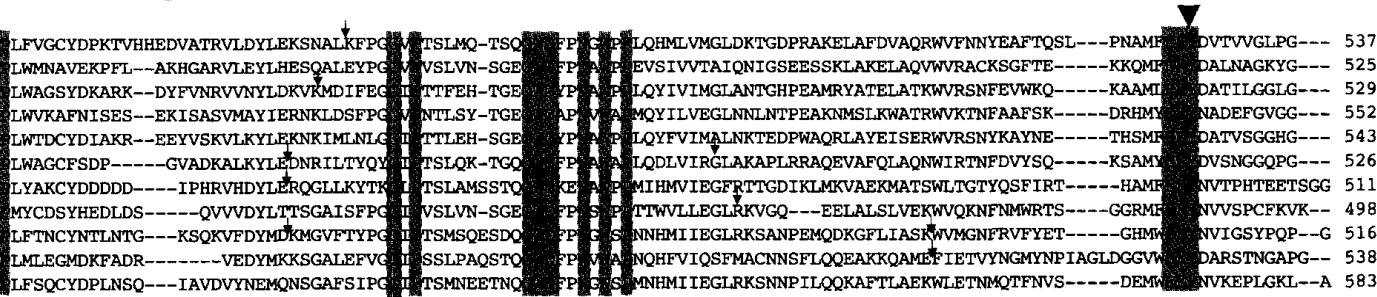

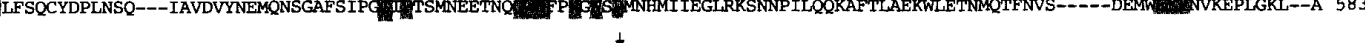

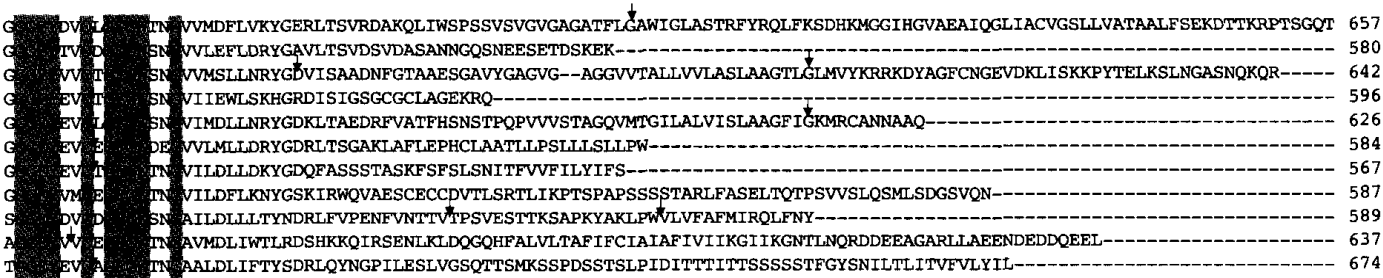
PQSSPTRRTKSL.'FFLLFORGSKGDEEHLIRNRAISEECSYSSIEE 703

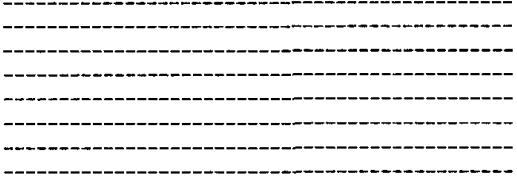
and Bm-2 [15, 16], fruit fly (Dm; CG9364 in database), European honeybee (Am; [25]), human (Hs; [9]) and Caenorhabditis elegans (Ce-1, Ce-2, Ce-3, Ce-4 and Ce-5; [23]) are aligned. Exon /intron boundaries are indicated by small arrows. Conserved boundary corresponding to S38 in Artemia trehalase is indicated by large arrowhead. Conserved boundary corresponding to K526/ Y527 in Artemia trehalase is indicated by gray arrowhead. Conserved amino acids are shaded in gray. 

-GGAGTTATCCTTGCTCTCGGGTTG GTGAGAACACTGTATACAATA ATTC-CTTGTACCAGACTGTTCGCCTGCTCAACATCTTTGTG-

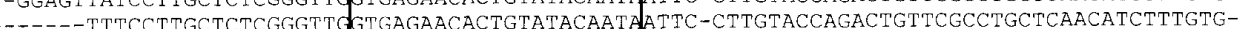
---GAGTTATCCTTGCTCTCGGGTTGGTGAGAACACTGTATACAATA A'TTC-CT TGTACCAGACTGTTCGCCTGCTCAACATCTTTGTGATGGAGTTATCCTTGCTCTCGGGTTGGTGAGAACACTGTATACAATA ATTC-CTTGTACCAGACTGTTCGCCTGCTCAACATCTTTGTG - AGAGTTATCCTTGCTCTCGGGTTOGTGAGAACACTGTATACAATA ATTC-CTTGTACCAGACTGTTCGCCTGCTCAACATCTTTGTG作 -..-ATTTAGTTATCAGTTCETCTTAAGCCTTCCAGCGAGIPAGTAGTGAACCGTTATCTTTTCCTTTAGTTTGGACT

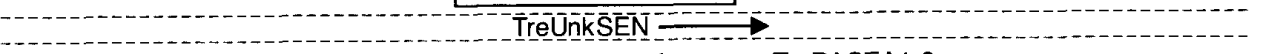

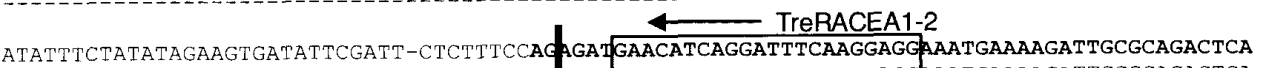
ATATTTCTGTATAGAAGTGATATTCGATT-CTCTTTCCAGAGA GAACATCAGGATTTCAAAGAGGAAATGAAAAGATTGCGCAGACTCA ATATTTCTGTATAGAAGTGATATTCGATT-CTCTTTCCAG AGA GAACATCAGGATTTCAAAGAGGAAATGAAAAGATTGCGCAGACTCA ATATTTCTGTATAGAAGTGATATTCGATT-CTCTTTCCACAGATGAACATCAGGATTTCAAAGAGGAAATGAAAAGATTGCGCAGACTCA ATATTTCTGTATAGAAGTGATATTCGATT-CTCTTTCCACAGATGAACATCAGGATTTCAAAGAGGAAATGAAAAGATTGCGCAGACTCA

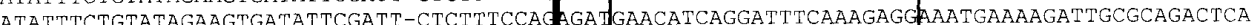
MATAG ARATTGTCTACAMGTGIOT TAGTCACCTAAAGTTA CAAGATTGGTCIACAAGGTG

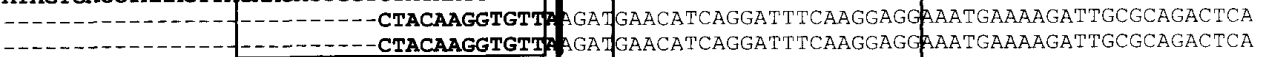
$\leftarrow$ TreUnkANT

GAGGAAAAGGTCCACCAAAGAA GGAGAAGGCAAACGTGCAAGTAAAAA-GTGAACTTTTGTTAGTGACTCTTGAAAAGAATAAAAGATA GAGGAAAAGGTCCACCAAAGA.AAGGAGAAGGCAAACGTGCAAG FAAAAAAGTGAACTTTTGTTAGTGACTGTTGAAAAGAATAAAAGATA GAGGAAAAGGTCCACCAAAGAAA GGAGAAGGCAAACGTGCAAG [AAAAAAGTGAACTTTTGTTAGTGACTGTTGAAAAGAATAAAAGATA

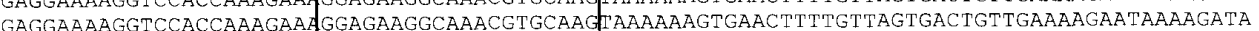

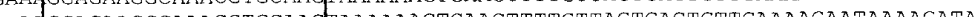
法 GAGGAAAAGGTCCACCAAAGAAAGGAGAAGGCA.ACGTGCAAGPAAAAAAGTGAAC.IIGIUAGTGACTGTTCAAAACAATAAAAGATA GAGGAAAAGGTCCACCAAAGAAAGGAGAAGGCAAACGTGCAAGPAAAAA-GTGAACTTTTGTTAGTGACTCTTGAAAAGAATAAAAGATA GAGGAAAAGGTCCACCAAAGAAAGGAGAAGGCAAACGTGCAAGPAAAAAAGTGAACTTTTGTTAGTGACTGTTGAAAAGAATAAAAGATA GAGGAAAAGTCCACCAAAGAAAGGAGAAGGCAAACGTGCAAGTAAAAA-GTGAACTTTTGTTAGTGACTCTTGAAAAGAATAAAAGATA GAGGAAACGGTCCACCAAAGAAA GGAGAAGGCAAACGTGCAAGTAAAAA-GTGAACTTTTGTTAGTGACTCTTGAAAAGAATAAAAGATA

translational start site TreRACES $1-2$ TreRACES2-2 TrTATCACTAAA AT GCGCATTTTTGAGTTTTTTCGTCGTTTTTGGATTTGCTACAACAGTTAGTTGTAGAGGCGATCTGGTTCTCA TTTTATCACTAAAdAT II GCGCATTTTTGAGTTTTTTCATCGTTTTTGGATTTGCTACAGCAGTIAGTTGTAGAGGCOATCTGATTCTCA TTTTATCACTAAA dATG IGCGCATTTTTGAGTTTTTTCATCGTTTTTGGATTTGCTACAGCAGTTAGTTGTAGAGGCOATCTGATTCTCA. TTTTATCACTAAA AT GGCGCATTT T TGAGTTTTTTCATCGTTTTTGGATT TGCTACAGCAGTTAGTTGTAGAGGCGATCTGATTCTCA TTTTATCACTAAA ATOFGCGCATTTT TGAGTTTTTTCATCGTTTTTGGATTTGCTACAGCAGTTAGTTGTAGAGGCGATCTGATTCTCA TTTTATCACTAAA DATGGCGCATTTTTGAGTTTTTTCATCGTTTTTGGATTTGCTACAGCAGTTAGTTGTAGAGGCGATCTGATTCTCA TTTTATCACTAAA AT OTGCGCATTT'TTGAGTTTTTTCGTCGTTTTTGGATTTGCTACAACAGTTAGTTGTAGAGGCQATCTGGTTCTCA TTTTATCACTAAA dATGTGCGCATTTT TGAGT TTTTTCATCGTTTTTGGATT TGCTACAGCAGT TAGTTGTAGAGGCGATCTGATTCTCA TTTTATCACTAAAdATG GCGCATTTTTGAGTTTTTTCGTCGTTTTTGGATT TGCTACAACAGTIAGTTGTAGAGGCOATCTGGTTCTCA TTTTATCACTAAA ATGGCGCATTTTTGAGTTTTTTCGTCGTTTTTGGATT TGCTACAACAGTIAGTTGTAGAGGCQATCTGGTTCTCA

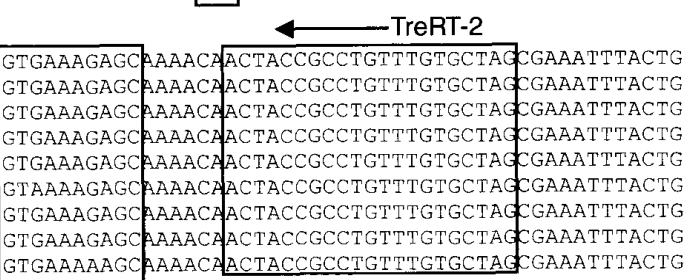

Fig. 3. A novel exon/intron boundary found by 5'RACE. 5'RACE products and partial sequence of Artemia trehalase cDNA, TreE2 [1] are aligned. A novel exon/intron boundary is indicated by vertical bold line. The new sequences found in four 5' RACE products (TreA2, TreA6, TreC9, TreC10) are indicated in bold letters. The $151 \mathrm{bp}$ sequence which is identical to ArMRP-S33 transcripts is indicated in red letters. Positions and direction of primers used in additional 5 , RACE (TreRT-2, TreRACES1-1, TreRACES1-2, TreRACEA1-2 and TreUnkANT) and 3'RACE (TreEX1sen.new and TreUnkSEN) are indicated by boxes and arrows, respectively. 

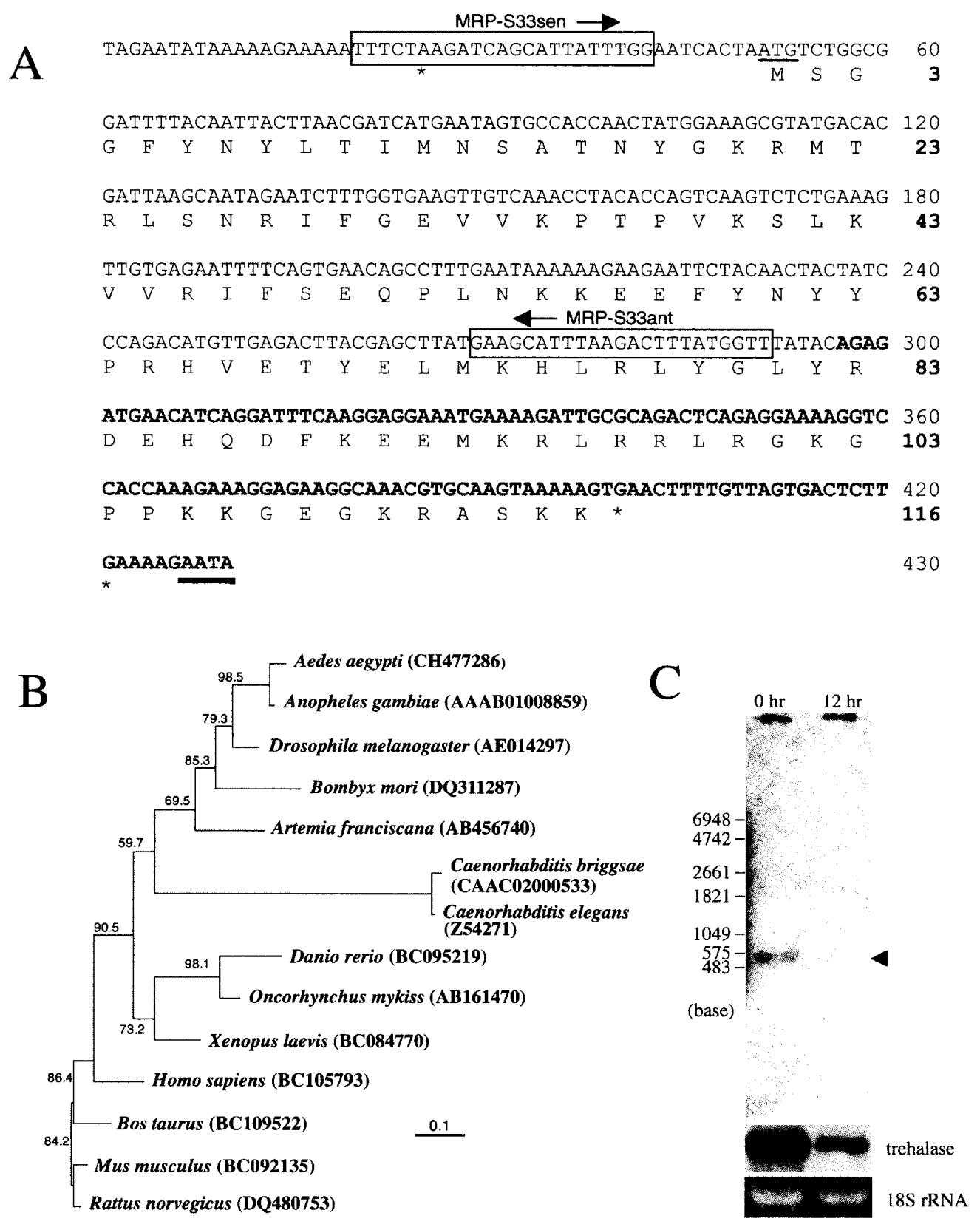

Fig. 4. Characterization of Artemia MRP-S33. A: Nucleotide and predicted amino acid sequences of $A r M R P-S 33$. The nucleotide and amino acid sequences are numbered from the first nucleotide and the first methionine. Asterisks indicate stop codons. The 134 nucleotides that were identical to the sequence downstream of the new exon/intron boundary found in the Exon I are indicated in bold letters. A truncated polyadenylation signel is heavily underlined. B: Phylogenetic analysis of animal MRP-S33 protein. Non-rooted neighbor-joining tree was drawn by GENETYX ver. 13 software. Scale bar indicates 0.1 expected amino-acid substitution per site. Values on each branching represent percent of bootstrap probability. C: Northern blotting of Artemia MRP-S33. Total RNA samples were extracted from Artemia nauplii at $0 \mathrm{hr}$ and $12 \mathrm{hr}$ of post-dormant development, and $20 \mu \mathrm{g}$ of each sample was electrophoresed, transferred to nylon membrane, and detected with DIG-labeled PCR probe. Positions of molecular weight markers are indicated. Position of MRP-S33 mRNA is indicated by an arrowhead. 
of insect proteins, showed a good agreement with the taxonomic position of Artemia.

Southern blotting to determine the copy number of the Artemia trehalase gene

To investigate the copy numbers of the Artemia trehalase gene, Southern blotting was performed using three kinds of DIG-labeled PCR probes, corresponding to parts of Exon I, IV and VI (probe I, IV and VI in Fig. 5). Only the probe I showed double signals in the sample digested by EcoRI. In the cases of probe IV and VI, the trehalase gene was detected as a single band.

\section{Detection of chimeric composition of trehalase transcripts}

In the 3'RACE analysis, we used three types of 5' primer: "TreEX1sen.new" corresponded to the 5' UTR of known trehalase cDNA (Fig. 3 and Table 1), "TreUnkSEN" corresponded to the novel 5' UTR found by 5'RACE (Fig. 3 and Table 1), and "MRP-S33sen" that is specific to ArMRP-S33 cDNA (Fig. 4A and Table 1). In the analysis using TreEX1 sen.new primer, subcloned PCR products were approximately $2.5 \mathrm{~kb}$ and had an open reading frame (Fig. 6), coding 703 amino acids. In the case of TreUnkSEN, we found two types of cDNA (Fig. 6 and 7). One was about $2.5 \mathrm{~kb}$ long and had an open reading frame coding the trehalase protein (Fig. 6, TreUnkSEN1 TreUnkSEN7, Fig. 7), as in the case of TreEX1sen. new. Except for the 5' end, the $2.5 \mathrm{~kb}$ cDNAs derived from the different primers had essentially the same exon composition, and the predicted amino acid sequences were 96-99\% identical to each other. Another type of PCR product obtained by TreUnkSEN primer was $0.3 \mathrm{~kb}$ (TreUnkSEN8 TreUnkSEN11, in Fig. 7). They had poly(A) tails at 15-17 base
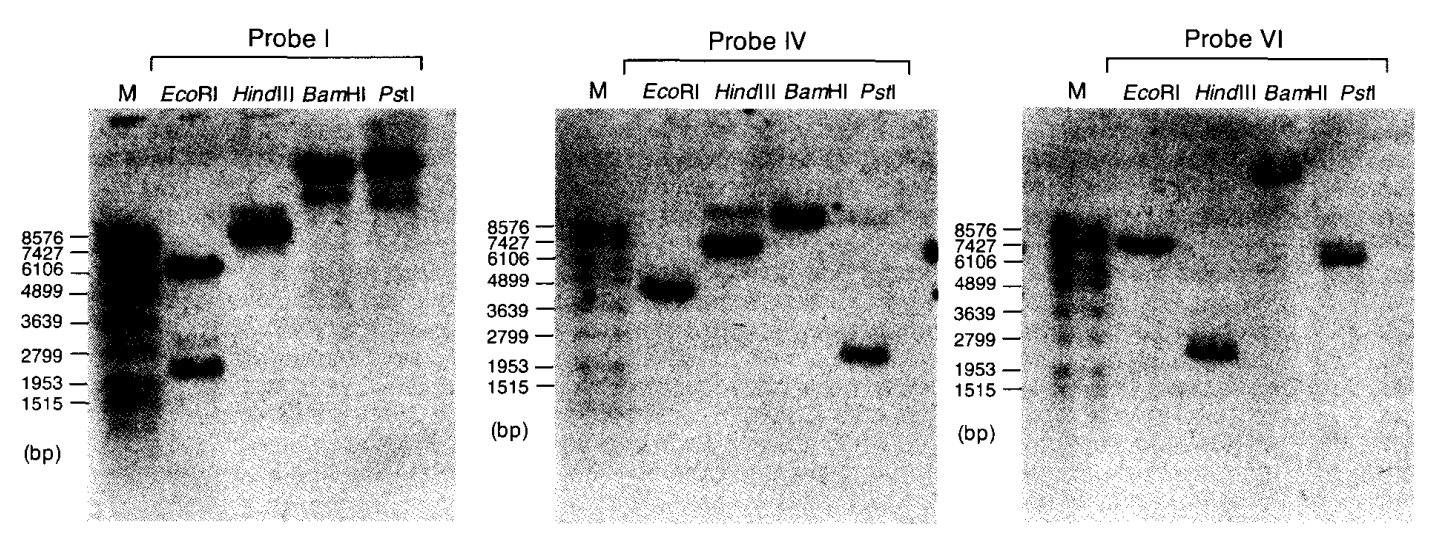

Fig. 5. Southern blot analysis of Artemia trehalase gene. DNA from Artemia nauplii digested with Eco RI, Hind III, Bam HI or PstI was hybridized with probe I, probe IV and probe VI labeled with digoxigenin. Digoxigenin-labeled molecular markers were used on the gel. 


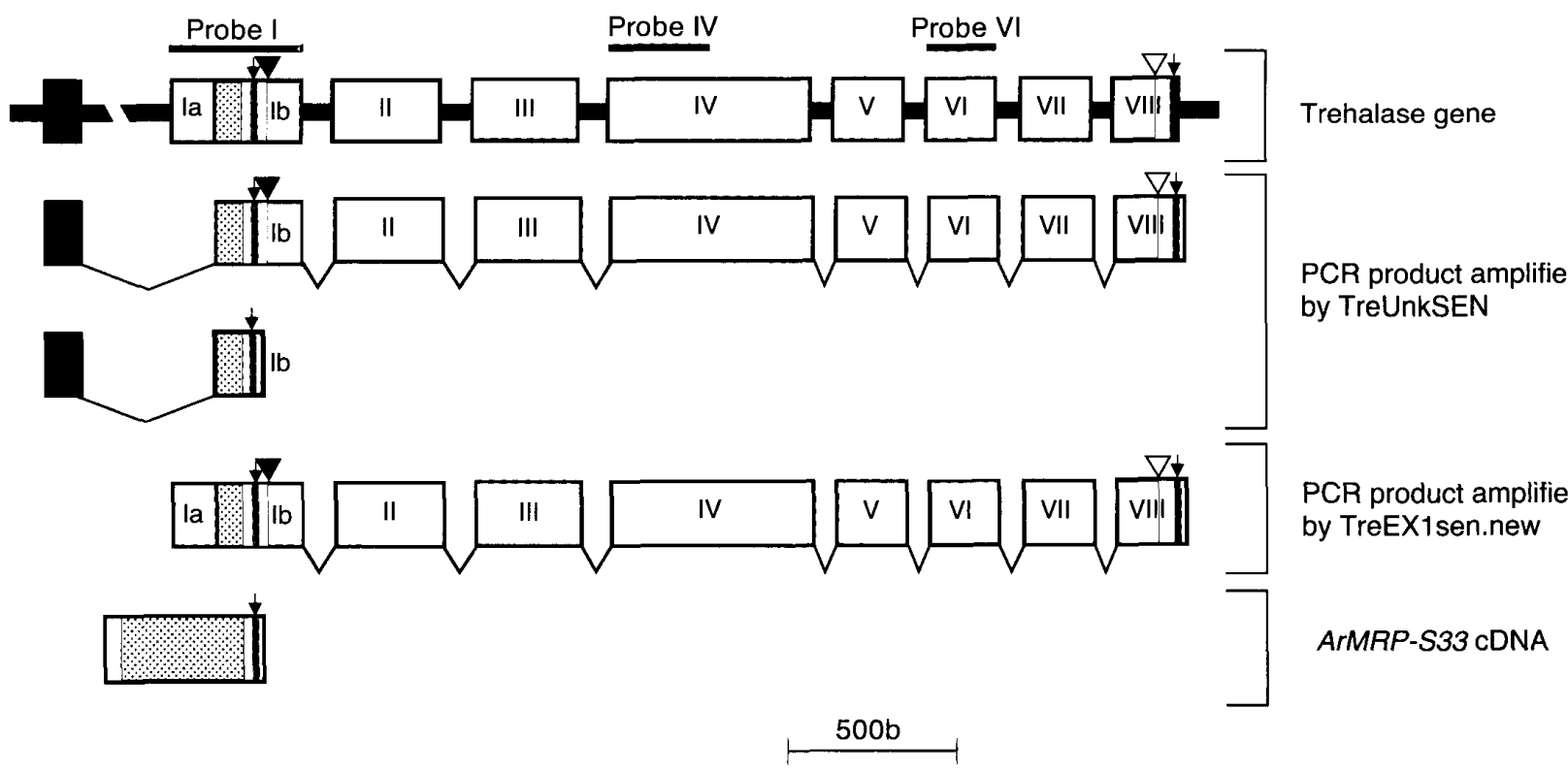

Fig. 6. Schematic diagram of Artemia trehalase gene and detected transcripts. Length of introns is deformed. Eight exons that corresponded to trehalase cDNA [1] are designated as Exon I-Exon VIII. Exon I is divided into Exon Ia and Exon Ib at a novel exon/intron boundary. A new sequence found in 5'RACE products is indicated as a black box. Polyadenylation signal sequences are indicated by small arrows and vertical gray lines. Dotted areas indicates coding region of Artemia trehalase and MRP-S33, respectively. Coding region of the trehalase is indicated by black arrowhead (translational start codon) and white arrowhead (stop codon). Positions of probes used in Southern blotting are indicated on trehalase gene with horizontal lines.

polyadenylation signal

\begin{tabular}{|c|c|c|c|c|}
\hline $\begin{array}{l}\text { MRP-S33-1 } \\
\text { MRP-S33-2 } \\
\text { MRP-S33-3 }\end{array}$ & TTGAAAAG & & $\begin{array}{l}\text { ATATTTTATCACTAAAAAAAAAAAA } \\
\text { ATATTTTATCACGCAAAAAAAAAAAAAA }\end{array}$ & $\begin{array}{l}442 \\
440 \\
443\end{array}$ \\
\hline $\mathrm{x} 1$. sen & & & GATATTTTATCACTAAACATGTGCGCATTTTTGAGTTTTTTCGTCGTTTTTGGATTTGCT & 302 \\
\hline EX1. sen . new2 & IG & & SATATTTTATCACTAAACATGTGCGCATTTTTGAGTTTTTTCATCGTTTTTGGATTTGCT & 302 \\
\hline reEX1.sen.new 3 & TTGAAAAG & AAT & ATATTTTATCACTAAACATGTGCGCATTTTTGAGTTTTTCGTCGTTTTTGGATTTGCTACAAC & 302 \\
\hline TreEX1. sen . new 4 & TTGAAAAG & & SATATTTTATCACTAAACATGTGCGCATTTTTGAGTTTTTTCGTCGTTTTTGGATTTGCTACAAC & 307 \\
\hline TreEx1. sen. new5 & TTGAAAAG & ATAAA & GATATTTTATCACTAAACATGTGCGCATTTTTGAGTTTTTTCGTCGTTTTTGGATTTGCTACAAC & 302 \\
\hline TreUnkSEN1 & Te & & ATATTTTATCACTAAACATGTGCGCATTTTTGAGTTTTTTCATCGTTTTTGGATTTGCTACAGC & 298 \\
\hline TreUnkSEN2 & TTGAAAAC & AAT & GATATTTTATCACTAAACATGTGCGCATTTTTGAGTTTTTTCATCGTTTTTGGATTTGCTACAGC & 297 \\
\hline TreUnkSEN3 & TTGAAAAG & AATZ & AGATATTTTATCACTAAACATGTGCGCATTTTTGAGTTTTTTCATCGTTTTTGGATTTGCTACAGC & 297 \\
\hline TreUnkSEN 4 & TTGAAAAG & AATA & МGATATTTTATCACTAAACATGTGCGCATTTTTGAGTTTTTTCATCGTTTTTGGATTTGCTACAGC & 297 \\
\hline TreUnkSEN5 & TTGAAAAG & ATAA & АGATATTTTATCACTAAACATGTGCGCATTTTTGAGTTTTTCATCGTTTTTGGATTTGCTACAGC & 297 \\
\hline TreUnkSEN6 & TTGAAAAG & ATAA & AGATATTTTATCACTAAACATGTGCGCATTTTTGAGTTTTTTCATCGTTTTTGGATTTGCTACAGC & 297 \\
\hline TreUnkSEN7 & TTGAAAAG & AATAA & AGATATTTTATCACTAAACATGTGCGCATTTTTGAGTTTTTTCATCGTTTTTGGATTTGCTACAGC & 298 \\
\hline TreUnkSEN8 & TTGAAAAG & AATAA & AGATATTTTATCACAAAAAAAAAAAAAAA- $-0-0-1-0$ & 260 \\
\hline TreUnkSEN9 & TTGAAAAG & AATZ & AGATATTTTATCACTGAAAAAAAAAAAAAAA- & 261 \\
\hline TreUnkSEN10 & TTGAAAAG & & AGATATTTTATCACTAAAAAAAAAAAAAAAAAAAAAAAAAAAAAAAAAAAAAAAAAAAAAAAAAAA & 298 \\
\hline TreUnkSEN11 & TTGAAAAC & ATAF & DGATATTTTATCACTAAAAAAAAAAAAAA-- & 269 \\
\hline
\end{tabular}

Fig. 7. Polyadenylation by signal sequence derived from $M R P-S 33$ gene. Four types of 3 ' RACE products amplified by three independent primers (MRP-S33sen, TreEX1sen.new and TreUnkSEN) were aligned. Sequences are numbered from the first nucleotide. 
downstream from the typical poly(A) additional signal, AATAAA, in the same way as MRPS33 cDNAs amplified by MRP-S33sen primer (MRP-S33-1 MRP-S33-3, Fig. 7).

\section{Discussion}

We re-constructed the Artemia trehalase gene using genomic clones isolated from a library derived from an inbred strain. The gene had 8 exons corresponding to the trehalase cDNAs reported in our previous study [1]. The eight exons ranged in size from 209 to 609 bp (Table 2). Seven introns ranged from $1.4 \mathrm{~kb}$ to $9.7 \mathrm{~kb}$ (Table 2). All the introns were in kilobase order, whereas those of mammalian trehalase genes were relatively small, except for the first one [9]. The rate of introns inserted in the coding area of Artemia trehalase was 94.7\%. The rates of introns found in the coding area of other trehalase genes are smaller than those found in the Artemia trehalase gene [9, 16, 23-25]. An extreme compaction of introns can be found in the silkworm trehalase-1 gene [15]. In this gene, there is no intron in the protein coding area. It has been reported that Artemia has a considerably large genome $\left(1.6 \times 10^{9}\right.$ bp) for an arthropod [26]. The redundancy in size of introns, such as those in the trehalase gene, may explain the large genome size of Artemia, to some extent. In order to obtain a 5' end of trehalase transcripts, 5'RACE was performed. The 5' end of the longest RACE product corresponded to position 7882 of the re-constructed trehalase gene. No typical TATA box sequence was found around this area.

The trehalase genes identified by the insect genome projects were seemingly different from those of mammals in their exon/intron conformation. In many cases, the genes of insect trehalase were composed of a small number of exons (2-7 exons), whereas the trehalase genes of the human and mouse contained small 15 exons [9]. However, a new trehalase gene found in the silkworm, trehalase-2, had 14 exons [16]. The trehalase gene reported from Spodoptera exigua also had 13 exons [27]. Contrary to these reports, the trehalase gene previously reported from the silkworm (trehalase-1) has only two exons [15]. Furthermore, five treha-

Table 2. Structure of the Artemia trehalase gene

\begin{tabular}{|c|c|c|c|c|c|}
\hline \multirow{2}{*}{ Exon name } & \multirow[t]{2}{*}{ Exon size(bp) } & \multicolumn{2}{|c|}{ Sequence at exon-intron junction } & \multirow[t]{2}{*}{ Codon interrupted } & \multirow[t]{2}{*}{ Intron size $(\mathrm{kb})$} \\
\hline & & 5' splice & 3'splice & & \\
\hline & & $\downarrow$ & $\downarrow$ & & \\
\hline I & $>390$ & TGCTAG GTAAGT & TTTCAG CGAAAT & S38 & 9.281 \\
\hline II & 326 & GGTTAG GTTGGT & TTTCAG GTCGAA & - & 4.297 \\
\hline III & 319 & TTTAAA GTAAGT & TCTTAG GCAAAA & K253 & 3.086 \\
\hline IV & 609 & CTTGAA GTAAGT & TTTAAG GTTTCC & K455 & 4.831 \\
\hline $\mathrm{V}$ & 214 & GAAAAG GTATTT & TTTTAG TATGAC & - & 1.437 \\
\hline VI & 212 & GATTGG GTAAGG & TTTTAG TCTTGC & G598 & 9.656 \\
\hline VII & 217 & TTACCC GTAAGT & TTCTAG GGCTTC & - & 4.343 \\
\hline VIII & 209 & & & & \\
\hline
\end{tabular}


lase genes of Caenorhabditis elegans were composed of 4-12 exons and have a large diversity in their patterns of exon/intron structure [23, Wormbase: http://www.wormbase.org/]. These findings suggested that trehalase genes could have a large diversity in their exon/intron structure, even in one species. The positions of the exon/intron boundary in the Artemia trehalase gene were compared with those in the trehalase genes of many species (Fig. 2). Boundaries corresponding to the position S38 of Artemia trehalase were found in insect, mammalian and nematoda trehalases (Fig. 2). Another boundary at K526/Y527 of the Artemia trehalase is conserved among most arthropods and mammals. Furthermore, several common exon/intron boundaries were also found among different phyla (Fig. 2). These common boundaries may reflect the evolutionary relationship of each trehalase gene.

We found a new exon/intron boundary in the 5' UTR region of the Artemia trehalase gene. A novel sequence was found at the 5' end of the cDNAs, using the 5'RACE method. This finding suggests another transcriptional start site of the trehalase gene. The novel 5' end sequence of the RACE products was not found in the reconstructed trehalase gene. This sequence seemed to exist in a much upper area of the reconstructed region. Unfortunately, this sequence was too short to synthesize useful screening probes, and genomic clones corresponding to this sequence have not been obtained yet. Gene walking or other efficient methods and laborious investigation will be needed to explore this region.

The $151 \mathrm{bp}$ sequence found in Exon I and trehalase cDNA (Fig. 3) was identical to the transcripts of ArMRP-S33. Although the short sequence could be found in the Artemia trehalase mRNA reported in our previous study [1], it was too short to be recognized at that time as a part of an ORF derived from another gene. There has been no report about the $M R P-S$ 33 sequence in trehalase genes hitherto reported. The $151 \mathrm{bp}$ sequence is $100 \%$ identical to the ArMRP-S33 transcripts and this strongly suggests that it was not so long ago when this sequence was inserted in the trehalase gene. A slight signal of ArMRP-S33 mRNA was detected in dormant cysts. The signal became undetectable in $12 \mathrm{hr}$-cultured embryos (Fig. 4C). Although the amount of ArMRP-33 transcript was much smaller than that of trehalase, its expression pattern was similar to the trehalase mRNA [1]. These results suggest that the ArMRP-S33 is one of the genes required in the early post-dormant development, as the trehalase is [1]. Human MRP-S33 is a product of a nuclear gene and one of the five MRPs suggested to be related to non-syndromic hearing loss [28]. The precise roles of ArMRP-S33 in Artemia dormant cysts and developing nauplii are not clear and need to be elucidated.

In many cases, the trehalase gene was detected as a single band in the Southern blotting. These results strongly suggest that this gene is a single copy, as we previously described [17]. Only probe I showed double signals in the sample digested by EcoRI (Fig. 5). As described above, Exon I had a sequence derived from ArMRP-33. Therefore, the double signals detected by probe I may be the original ArMRP-33 and its partial copy inserted in the trehalase gene. However, this does not mean that the gene described in the present report is the only trehalase gene in the Artemia genome. In screening of the trehalase gene in the 
silkworm, the gene of the membrane-penetrating trehalase was not detected by a probe derived from the soluble trehalase cDNA [15]. In a previous report, we pointed out that the molecular mass of the Artemia membrane-bound trehalase without the membrane-binding region was almost equal to the size of the soluble trehalase that we had purified $[1,5]$. Therefore, we speculated that the soluble-type trehalase might be generated by the cleavage of the membrane-bound trehalase. However, the presence of other genes coding the soluble trehalase is still possible. Mammals appear to have a single trehalase gene in their genomes, whereas the silkworm, fruit fly and honeybee have at least two trehalase genes $[9,16,23-$ 25]. Pellerone et al [23] reported five trehalase genes of Caenorhabditis elegans. These findings owed a large part of themselves to genome projects or systematic cDNA databases. A comprehensive EST research or genome project in Artemia may bring rapid progress in this field.

We revealed that an alternative polyadenylation site has been introduced into the 5' UTR of the Artemia trehalase gene. As a result of the polyadenylation at this site, chimeric transcripts that had the 5' UTR region of trehalase and 3' end of MRP-S33 with poly(A) tail could be transcribed (Fig. 6,7). Such a composition of mRNA is quite interesting because the short transcript has no coding region of trehalase. If all of the transcripts were truncated by the poly(A) signal in the ArMRP-S33 sequence, no trehalase protein would be synthesized. These findings strongly suggest the presence of a control mechanism of polyadenylation in the 5' UTR of trehalase mRNA. Recent progress in genome researches revealed that alternative polyadenylation could be found in various organisms [29-31]. The alternative polyadenylation signal found in the Exon I of the Artemia trehalase gene is unique because it was derived from another gene and was newly introduced during the evolution of the trehalase gene. Winter et $a l$. reported that alternative polyadenylation signals are related to the tissue-specific expression of the Opitz Syndrome gene MIDI [32]. It is quite an attractive question whether the novel alternative polyadenylation site in the trehalase gene regulates the trehalase activity and/or tissue-specific expression.

\section{Acknowledgement}

This study was partly supported by a grant from the Ministry of Education, Science, Sports and Culture of Japan (15770089) given to S.T.. DNA sequencing was performed with equipment in the Bio-information Research Center in the University of Occupational and Environmental Health, Japan.

\section{References}

1. Tanaka S, Nambu F \& Nambu Z (1999): Cloning and characterization of cDNAs encoding trehalase from post-dormant embryos of the brine shrimp, Artemia franciscana. 
Zool Sci 16: 269-277

2. Crowe JH, Crowe LM, Carpenter JF \& Wistrom CA (1987): Stabilization of dry phospholipid bilayers and proteins by sugars. Biochem J 242: 1-10

3. Crowe JH, Crowe LM, Carpenter JF, Rudolph AS, Wistrom CA, Spargo BJ \& Anchordoguy TJ (1988): Interactions of sugars with membranes. Biochim Biophys Acta 947: $367-$ 384

4. Clegg JS (1965): The origin of trehalose and its significance during the formation of encysted dormant embryos of Artemia salina. Comp Biochem Physiol 14: 135-143

5. Nambu Z, Nambu F \& Tanaka S (1997): Purification and characterization of trehalase from Artemia embryos and larvae. Zool Sci 14: 419-427

6. Ruf J, Wacker H, James P, Maffia M, Seiler P, Galand G, von Kieckebusch A, Semenza G \& Matei N (1990): Rabbit small intestinal trehalase. Purification, cDNA cloning, expression, and verificational glycosylphosphatidylinus anchoring. J Biol Chem 265: $15034-15039$

7. Sasai-Takedatsu M, Taketani S, Nagata N, Furukawa T, Tokunaga R, Kojima T \& Kobayashi Y (1996): Human trehalase: characterization, localization, and its increase in urine by renal proximal tubular damage. Nephron 73: 179-185

8. Ishihara R, Taketani S, Sasai-Takedatsu M, Kino M, Tokunaga R \& Kobayashi Y (1997): Molecular cloning, sequencing and expression of cDNA encoding human trehalase. Gene 202: 69-74

9. Oesterreicher TJ, Markesich DC \& Henning SJ (2001): Cloning, characterization and mapping of the mouse trehalase (Treh) gene. Gene 270:211-220

10. Azuma M \& Yamashita O (1985): Cellular localization and proposed function of midgut trehalase in the silkworm larva, Bombyx mori. Tissue Cell 17: 539-551

11. Azuma M \& Yamashita O (1985): Immunohistochemical and biochemical localization of trehalase in the developing ovaries of the silkworm, Bombyx mori. Insect Biochem 15: $589-596$

12. Valaitis AP \& Bowers DF (1993): Purification and properties of the soluble midgut trehalase from the gypsy moth, Lymantria dispar. Insect Biochem Mol Biol 23: 599-606

13. Wyatt GR (1967): The biochemistry of sugars and polysaccharides in insects. Adv Insect Physiol 4: 287-360

14. Yaginuma T, Mizuno T, Mizuno C, Ikeda M, Wada T, Hattori K, Yamashita O \& Happ GM (1996): Trehalase in the spermatophore from the bean-shaped accessory gland of the male mealworm beetle, Tenebrio molitor: purification, kinetic properties and localization of the enzyme. J Comp Physiol B 166: 1-10

15. Su Z-H, Itani Y \& Yamashita O (1997): Structure of trehalase gene of the silkworm, Bombyx mori and phylogenetic relationship of trehalases. J Sericultural Sci Japan 66: $457-$ 465

16. Mitsumasu K, Niimi T, Yamashita O \& Yaginuma T (2006): Diapause hormone-enhanced 
expression of the trehalase- 2 gene encoding a novel membrane-penetrating type in Bombyx developing ovaries and the gene structure. J Insect Biotechnol Sericology 75: $71-$ 77

17. Nambu Z, Tanaka S \& Nambu F (1997): Gene expression of trehalase during post-dormant development of the brine shrimp, Artemia: comparison of the two species. J UOEH 19: $255-264$

18. Nambu F, Tanaka $S$ \& Nambu Z (2007): Inbred strains of brine shrimp derived from Artemia franciscana: Lineage, RAPD analysis, life span, reproductive traits and mode, adaptation, and tolerance to salinity changes. Zool Sci 24: 159-171

19. Sambrook J, Fritsch EF \& Maniatis T (1989): Identification and Analysis of Recombinants; in Molecular cloning. In: A Laboratory Manual. (Sambrook J Frish EF\&Maniatis $\mathrm{T} e d)$. Cold spring harbor laboratory press, New York pp 1.90-1.101

20. Engler-Blum G, Meier M, Frank J \& Müller GA (1993): Reduction of background problems in nonradioactive northern and Southern blot analyses enables higher sensitivity than ${ }^{32}$ P-based hybridizations. Anal Biochem 210: 235-244

21. Maruyama IN, Rakow TL \& Maruyama HI (1995): cRACE: a simple method for identification of the 5' end of mRNAs. Nucleic Acids Res 23: 3796-3797

22. Koc EC, Burkhart W, Blackburn K, Moseley A \& Spremulli LL (2001): The small subunit of the mammalian mitochondrial ribosome. I dentification of the full complement of ribosomal proteins present. J Biol Chem 276: 19363-19374

23. Pellerone FI, Archer SK, Behm CA, Grant WN, Lacey MJ \& Somerville AC (2003): Trehalose metabolism genes in Caenorhabditis elegans and filarial nematodes. International J Parasitol 33: 1195- 1206

24. Mitsumasu K, Azuma M, Niimi T, Yamashita O \& Yaginuma T (2005): Membrane-penetrating trehalase from silkworm Bombyx mori. Molecular cloning and localization in larval midgut. Insect Mol Biol 14: 501-508

25. Lee JH, Saito S, Mori H, Nishimoto M, Okuyama M, Kim D, Wongchawalit J, Kimura A \& Chiba S (2007): Molecular cloning of cDNA for trehalase from the European honeybee, Apis mellifera L., and its heterologus expression in Pichia pastoris. Biosci Biotechnol Biochem 71: 2256-2265

26. Marco R, Garesse R \& Renart J (1991): Artemia molecular genetics; In: Artemia Biology. (Browne RA, Sorgeloos P \& Trotman CNA ed). CRC press, Boca Raton, Florida pp $1-19$

27. Tang B, Chen X, Liu Y, Tian H, Liu J, Hu J, Xu W \& Zhang W (2008): Characterization and expression patterns of a membrane-bound trehalase from Spodoptera exigua. BMC Mol Biol 9: 51

28. O’ Brien TW, O’ Brien BJ \& Norman RA (2005): Nuclear MRP genes and mitochondrial disease. Gene 354: $147-151$

29. Hughes TA (2006): Regulation of gene expression by alternative untranslated regions. 
TRENDS Genet 22: $119-122$

30. Ara T, Lopez F, Ritchie W, Benech P \& Gautheret D (2006): Conservation of alternative polyadenylation patterns in mammalian genes. BMC Genomics 6: 189

31. Shen Y, Ji G, Haas BJ, Wu X, Zheng J, Reese GJ \& Li QQ (2008): Genome level analysis of rice mRNA 3' -end processing signals and alternative polyadenylation. Nucleic Acids Res 36: $3150-3161$

32. Winter J, Kunath M, Roepcke S, Krause S, Schneider R \& Schweiger S (2007): Alternative polyadenylation signals and promoters act in concert to control tissue-specific expression of the Opitz Syndrome gene MIDI. BMC Mol Biol 8: 105 
アルテミアトレハラーゼ遺伝子の持つ特異な構造について

田中 晋1, 南部 文子' ${ }^{1}$ 南部 滋郎 2

1産業医科大学 産業保健学部 人間情報科学

${ }^{2}$ 日本赤十字九州国際看護大学

要 旨： 小型甲殼類アルテミアのトレハラーゼ遺伝子の構造解析を行うため, 近交系アルテ ミア由来のゲノムライブラリーから得られた4つのクローンに基づいてアトレハラー ゼ遺伝子を含む $49 \mathrm{~kb}$ の領域を再構築した。この領域内には以前我々が報告したトレ ハラーゼ cDNA に対応する8つのエキソンが存在していた．他の動物で報告されてい るトレハラーゼ遺伝子と構造を比較した結果, 動物界を超えて保存されているエキ ソン/イントロン境界が存在していることが判明した，5’RACE 法によりトレハラー ゼ mRNA とトレハラーゼ遺伝子の関係を解析し，エキソンIの領域内にこれまで知 られていなかったエキソン/イントロン境界が存在することを明らかにした。また， ミトコンドリアのリボソームタンパク質（MRP.S33）遺伝子の一部のコピーがトレハ ラーゼ遺伝子の5’側の領域に組み込まれていることが判明した。組み込まれた配列 は本来の MRP-S33が持っていたポリA付加シグナルを保持していた. 3’RACE 法に より，このポリ $\mathrm{A}$ 付加シグナルが依然として機能しており，その結果としてトレハ ラーゼ mRNA の5’UTRと MRP-S33遺伝子の3’末端をもった短いキメラ mRNA が転 写され得ることが示された.

キーワード： アンハイドロビオシス,アルテミア,ブラインシュリンプ, 選択的スプライシング, 選択 的ポリA付加.

J UOEH（産業医大誌）32（1）：11-29（2010） 